\title{
貫穴楔代から見た東大寺南大門の部材構成と軸部組立工程について COMPONENTS AND ASSEMBLING PROCESS OF TODAI-JI GREAT SOUTH GATE FROM AN OBSERVATION OF CROSSPIECE HOLES AND THEIR WEDGES
}

\author{
林琳*1, 清 水重敦*2
}

\section{Lin LIN and Shigeatsu SHIMIZU}

\begin{abstract}
This research is based on the Report Book Of Repair Construction and observing crosspiece holes in columns of Todai-ji Great
\end{abstract} South Gate. Carrying out by the following methods.

1. Examined the peculiar description method.

2. Based on the observation in field survey, made the actual condition of crosspiece holes and wedges clear, analyzed the shape of joint and crosspiece inserted to the crosspiece holes and their assembly order.

3. Re-inspected the types and dimensions of components recorded by the Report book of repair construction, revised their position.

4. Restored the assembly process of its main framework.

Keywords : $\quad$ Todai-ji Great South Gate(Nandaimon), Assembling process, Wedge, Crosspiece,

Inserted bracket arms (Sashihijiki), Joint (Shiguchi)

東大寺南大門, 組立工程, 楔代, 貫, 挿肘木, 仕口

\section{1. 研究の背景と目的}

鎌倉初期に建立された東大寺南大門については、大仏様建築の代 表例として、これまでに数多くの研究がなされてきた。大仏様の様 式・技法、中国宋代建築との関係、東大寺の造営組織や重源の事績、

そして南大門自体の研究も数多く行われている。

大仏様の技術的観点からの研究は、挿肘木や遊離尾垂木など、細 部技法に着目した研究がその多くを占めている。もちろんその観点 からの研究は大仏様の技術的な本質や、中国との関係を考える上で 欠くことができないものであるが、現存する中国建築における類例 との差違とその意味について、あまり指摘されてこなかった点があ る。それは大仏様の源流の一つと目される中国の穿斗式の構造技法 と大仏様の貫の差違である。穿斗式では、主たる構造は梁行に並ぶ 柱と貫で形成され、これらの主構造体が梁行の貫から上下位置をず らした貫によって桁行に繋がれる。一方、大仏様では梁行と桁行に 貫形状の差がなく、また上下位置も揃うため、各柱では貫が四方差 しとなり、柱への貫の仕口、貫同士の組手が格段に複雑になる。

また、そもそも大仏様とは巨大建築としての東大寺大仏殿を再建 することに導入の主目的があったはずで、細部の技法にも増し、全 体の架構や組立工程にこそ重要な意味があったと考えるべきである う。貫の組手が複雑なため、組立工程にも中国穿斗式のそれとは異

\footnotetext{
*1 京都工芸瀻維大学工芸科学研究科建築学専攻 大学院生 - 修士 (工学)

*2 京都工芸瀻維大学デザイン・建築学系 教授・博士 (工学)
}

なる点があることが想定されよう。

数多くの先行研究の中で、東大寺南大門の組立過程に着目したも のとして、池浩三氏等による「東大寺南大門の構成部材一軸部の肘木 と貫」注1) がある。当論文は、『東大寺南大門史及昭和修理要録』(以 下では『修理要録』と略称する。）を資料に、南大門の軸部水平材の 仕口に着目し、その復元考察を行うとともに、架構の部分模型を作 成し、南大門全体の組立工程を推定している。その結果、東大寺南 大門の組立が、足場を用いずに施工される極めて合理的かつダイナ ミックなものであり、その特異な構造形式がこの組立工程と関連を 持つものであったことが明らかにされた。こうした組立工程そのも のも大仏様の技術的な特徴の一つであることがここに明らかにされ たわけだが、筆者らはその論述過程にいくつかの問題があると考え る。主に以下の 3 点が挙げられる。

(1)部材の検証の中で、挿肘木のように繰り返して用いられ、外観 上は同形式である部材について、部材長や仕口を全て同形式として 扱っている。これは組立工程を前後左右対称なものとする想定に基 づく理解であり、組立工程によっては特異な形状を持つ部材が生じ る可能性を考慮していない。

(2)『修理要録』では挿肘木の最長值を 48 尺と記録している。池 氏はこの最長值を第七層注 2) の隅行挿肘木の寸法と推定しているが、

Grad. Student, Dept. of Architecture, Graduate School of Science and Technology, Kyoto Institute of Technology, M.Eng. Prof., Dept. of Architecture, Graduate School of Science and Technology, Kyoto Institute of Technology, Dr.Eng. 
Table1 Measures of Crosspiece and Inserted bracket arms from Report book of repair construction

\begin{tabular}{|c|c|c|c|c|c|c|}
\hline \multicolumn{7}{|c|}{ 貫と肘木の寸法情報 } \\
\hline \multirow{2}{*}{ 記録出典 } & \multirow{2}{*}{ 記録 } & \multirow{2}{*}{ 部材名 } & \multicolumn{3}{|c|}{ 寸法(単位 : 尺) } & \multirow{2}{*}{ 数 } \\
\hline & & & 成 & 厚 & 長さ & \\
\hline \multirow{2}{*}{$\begin{array}{c}\text { 第五章 エ、事実施仕様 } \\
\text { 三、木部 }\end{array}$} & 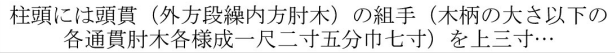 & 貫肘木 & 1.25 & 0.7 & 無し & 無し \\
\hline & 通肘木の大さ成一尺二寸五分厚七寸のもの $\cdots$ & 通肘木 & 1.25 & 0.7 & 無し & 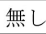 \\
\hline \multirow{5}{*}{ 第八章＼cjkstart諸種の統計 } & $\begin{array}{c}\text { 挿肘木 長三尺乃至四十八尺、セイ一尺二寸五分、厚七寸。四 } \\
\text { 百十八丁 }\end{array}$ & 挿肘木 & 1.25 & 0.7 & $\begin{array}{l}\text { 最短: } 3 \\
\text { 最長: } 48\end{array}$ & 418 \\
\hline & 通肘木 長二十尺、セイ厚同寸。六十丁 & 通肘木 & 1.25 & 0.7 & 20 & 60 \\
\hline & 振止通肘木 長七尺乃至廿尺、セイ厚同寸。百井二丁 & 振止通肘木 & 1.25 & 0.7 & $\begin{array}{l}\text { 最短 : } 7 \\
\text { 最長 : } 20\end{array}$ & 132 \\
\hline & 秤肘木 長五尺一寸、セイ厚同寸。百四丁 & 秤肘木 & 1.25 & 0.7 & 5.1 & 104 \\
\hline & 樌 長十八尺乃至二十尺、セイ尺二寸五分、厚七寸。四十九丁 & 貫 & 1.25 & 0.7 & $\begin{array}{l}\text { 最短 : } 18 \\
\text { 最長 : } 20\end{array}$ & 49 \\
\hline
\end{tabular}

当該部材の実寸法と一致しないため、48 尺に比定しうる他の部材を 探す必要がある。

(3)軸部の貫の柱貫穴内における複雑な仕口の形状及び寸法を、修 理要録』の本文に記載される寸法と挿図から復元しているが、この 復元寸法では棟通り柱における四方差しの仕口が相欠きにならず、 構造上機能しない仕口となってしまう。

これらの問題点に対し、筆者らは東大寺南大門の現地調查により、 問題を解決する要素を見出した。それは、各柱に多数穿たれた貫穴 の形状とその配置である。南大門の貫穴成はいずれも貫成より高く とられ、上部を楔代とするが、楔代成には大小の 2 種類がある。こ の楔代成の差違が貫の組立順序と関連寸るものであることが池氏等 によって明らかにされている。貫穴の仕口自体は南大門の昭和修理 における構造補強により改変されているが、楔代については現地観 察により確かに大小 2 種類あることが確認でき、当初形式を残して いることがわかる。この楔代を子細に観察したところ、その配置に 一定の規則が見られながらも、池氏等の想定とは異なり、不規則な 配置が見られる箇所が多々あることが判明した。これを検討するこ とで、柱及び貫・挿肘木の施工順序を見直すことができると考えた。

南大門の架構形式を見ると、軸部と小屋組が大虹梁を境に上下に 分離しているため、軸部を小屋組から切り離して考えることができ る。本論文は、東大寺南大門の柱に穿たれた貫穴楔代の観察を元に、 『修理要録』に掲載された大虹梁以下の軸部部材の仕口形状と寸法 を再検証し、その位置の再比定を行い、その上で東大寺南大門の軸 部組立工程を改めて復元し、その意義を考察することを目的とする。

なお本論文は、両筆者が共同で東大寺南大門の現地検証を調査を 行う中でその根幹をな寸発見をするに至り、その成果をもって林が 執筆し、清水が論文の全体調整を行ったものである。

\section{2. 研究の対象と方法}

本研究は東大寺南大門の貫穴に見られる楔代の成の現地調查を考 察の主軸に置くものである。楔代については既往研究に言及されて いるものの、実態に即したものではなかったため、楔代成を基にし た既往研究による『修理要録』記載の部材種類・寸法・仕口の解釈 には誤りがあると考えざるを得ない。

本研究では、まず『修理要録』における部材の記載方法と寸法取 りの方法を検証し、特有の記載方法を把握する。次に、現地調查に 基づく貫穴楔代成の実態を明らかにし、仕口形状、縦横の貫穴にお ける貫の形状と組立順序を分析する。その上で、『修理要録』記載の
部材種類と寸法を見直し、部材位置の再比定を行う。以上全てをふ まえて、軸部の組立過程を復元する。尚、本論では便宜上、水平部 材である挿肘木または貫で構成される水平面を「層」と名付け、最 下層より番付を行う。(Fig.1)

\section{3．『修理要録』における部材情報の記載方法}

まず『修理要録』における部材の種類・員数・寸法の記載方法を 検討する。

『修理要録』で部材の情報が言及されるのは、「第五章 工事実 施仕様 三、木工の部」、第八章 諸種の統計」と「実測図版」で ある。これらに記載される貫注 ${ }^{3)}$ 、挿肘木等水平部材の寸法情報を Table1 と Fig. 2 によめる。これらの他に、「添承挿肘木」が本文 中に言及されるが、この部材については員数、寸法の記載がない。 この『修理要録』は修理工事報告書草創期の昭和 5 年に出版さ れたもので、昨今の修理工事報告書とは異なって形式が未整備な面 があり、材長の採り方や部材名称などに曖昧さが多々見られる。例 えば部材名称として「貫」、「頭貫」、「科肘木」、「挿肘木」、「通肘木」、 「振止通肘木」が挙げられるが、南大門の場合、これらの部材は同 一の断面形状をとり、柱一の仕口も共通しているため、部材名称と 使用位置の同定がまず問題となる。よって、『修理要録』特有の記 載ルールを見出すことから始めたい。

\section{（1）水平部材の位置比定と「材長」}

各名称で呼ばれる水平部材の位置については、池氏等によって比 定されている。「頭貫」は柱頭に渡される貫、「挿肘木」は組物を構 成する时木で、その一部は側柱を貫通して棟通柱に達する。「通肘 木」は側柱筋に渡される壁付きの肘木、「振止通肘木」は層 4、6、 7、15、17、18 組物手先に渡されて組物の間を繋ぐ肘木である。概 ね納得できる比定であるが、「材長」を子細に検討すると再考の必 要な箇所が見えてくる。

「材長」は一般的に部材の全長を指すが、当「修理要録」におけ る「材長」は全長ではなく、組手や斗の心で採寸したものが多い。 またその採寸箇所に統一性を欠く面がある。修理要録』によれば、 南大閒の桁行方向の柱間寸法は現尺で記されており、東から「17.8 尺」、「19.8 尺」、「19.8 尺」、「19.8 尺」、「17.8 尺」、梁行方向の柱 間寸法は「17.8尺」「17.8 尺」である注4)。それらに対して、柱間 に通される貫の「材長」の最短值は「18 尺」、最長値は「 20 尺」注 5) と、また通肘木の材長は全て「20 尺」注 6) と、いずれも整数值 で記される。 

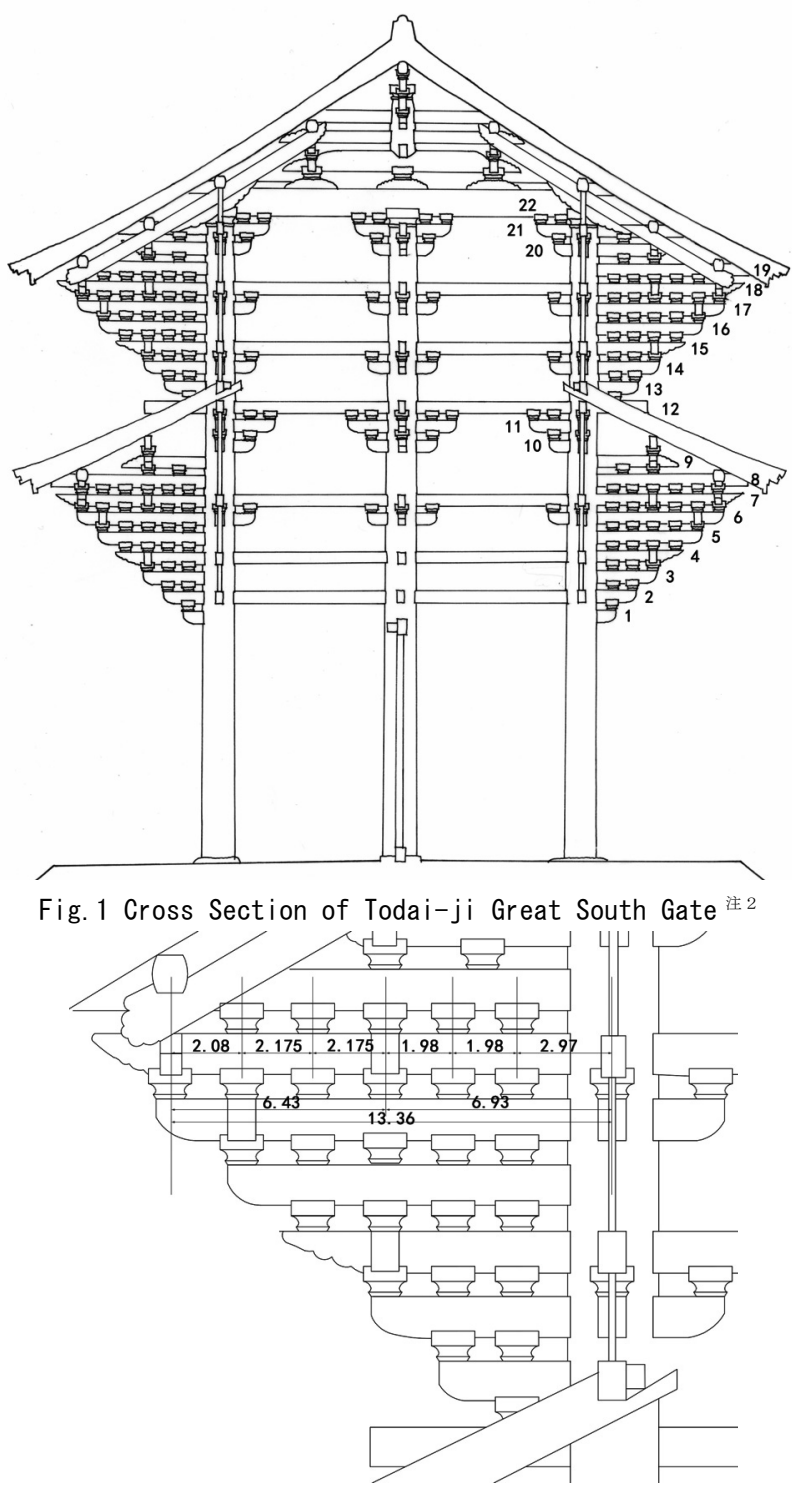

Fig. 2 Part of Inserted bracket arms from Layer12 to Layer 19

柱間寸法とそこに通される「貫」及び「通肘木」の材長の差 0.2 尺は、仕口において柱心を越える部分の寸法とみることもできるが、 貫及び通肘木の仕口は「実測図版 第十三」によれば柱心より 1.05 尺外に出るので、0.85 尺の差を大きく上回る。従って『修理要録』 の貫または通肘木の「材長」は、仕口の寸法を含めずに、柱心々寸 法を四捨五入したものと考えられる。

「挿肘木」は材の一端のみが柱に貫入し他方は持ち放しとなるた め、別個に材長を解釈する必要がある。挿肘木の材長の最短值は「3 尺」で、この部材は一手目の挿肘木と推定される。一方実測図では、 柱真からこの一手目の挿肘木上巻斗の心までの距離が「2.97 尺」 と記されている(Fig.2)。材長として記録された 3 尺との差はわず かであり、挿肘木の材長が柱心と先端の巻斗心の間の距離を指寸も のであることがわかる。他の部材と同じく、仕口の寸法を含んでい ない。

以上のように『修理要録』に記載される材長は、木鼻を含む材端 部と仕口の寸法を含まず、柱心と巻斗心に基準を置いて採寸したも
のとみられる。

\section{（2）記載寸法の精度}

『修理要録』の寸法は「尺、寸、分」を単位としている。記入方 法の特徴として垂直方向と水平方向の精度が異なっている。

柱、大瓶束のような垂直材、また斗の幅、貫材の「セイ」などの 垂直方向の寸法は「分」まで記入されているが、水平方向の精度は 全体的に垂直方向より低い。

また、部材ごとに精度も変わっていく。例えば貫、通肘木、挿肘 木などの柱間の繋ぎ材の長さは、前述の如く四捨五入して「尺」単 位で記入される。一方、同じく「肘木及樌」の項目に記される秤肘 木と実肘木、また大虹梁、妻大虹梁、隅木など大断面の横材の長さ は「寸」単位までしか記されない。これらの部材は両端が柱より外 に持ち出されることが共通しており、実測の方法が柱間の繋ぎ材と 異なると考えられる。

挿时木寸法に関して先述したように、同じ部材に対して、本文部 分で記載される寸法と実測図面の上で標記される寸法の精度が異な る場合もある。

つまり『修理要録』の記載寸法は昨今の修理工事報告書のような 詳細且つ精確なものとはいえず、部材ごとに採寸箇所や精度を確認 していく必要がある。

\section{（3）挿肘木の最短値と最長値}

挿肘木、振止通肘木と貫の材長は使用位置によって異なるが、『修 理要録』では最短值と最長值しか掲載されていない。挿肘木の最短 值は「3 尺」であり、これは層 1 の挿肘木（Fig.1）に比定できる。

一方、挿肘木の最長值である「48 尺」は図面上には直接現れない ため、使用位置を推測する必要がある。池氏はこの部材を初層組物 の最上段である層 7 の隅行挿肘木としたが、実測図面に記される棟 通柱心から当層の平の挿肘木先端巻斗心までの距離 31 尺 1 寸 6 分 より計算すると隅行挿肘木長は 44 尺となり、寸法が不足する。ま た平の挿肘木の木鼻先端までの距離 33 尺 3 寸より計算すると 47 尺 9 分となり、これも若干短い。且つ、当報告書においては木鼻先端 までの距離で計算する類例がない、得られた数值の信憑性が足りな い。従って「48 尺」に該当する部材を改めて検討する必要がある。

\section{4. 貫穴楔代の寸法と配置}

\section{（1）貫の仕ロ・組手と貫穴形状}

現地調查に基づき、各柱に開けられた貫穴について、詳細に見て いこう。東大寺南大門の柱間に縦横に配される貫は、梁行と桁行が 同高に通され、側柱より内側では貫、側柱筋では通肘木となる。さ らにそれらが側柱の外に伸びて挿肘木となっている。これらはす心゙ て同一断面の部材であり、柱への仕口と柱内における組手は複雑な 形状を採る。

仕口の様子については、その基本形式について、『修理要録』の「通 肘木」に関連して以下の記述がある。

「片鬢太長さ二尺ー寸横に段欠きに抱き合はせ、内面に於いては （A）図の如く段懸かり七寸腰高五寸、他方の貫当り相欠きの個所 深一寸五分巾七寸に造りたるものを、先ず左右継手を柱柿穴内に 差合はせたる後、更に直角に組合はさるべき組手を同様柱の柿穴 内に通し込み、前に挿入仕合せ置きたる継手に相欠きに落込み、 


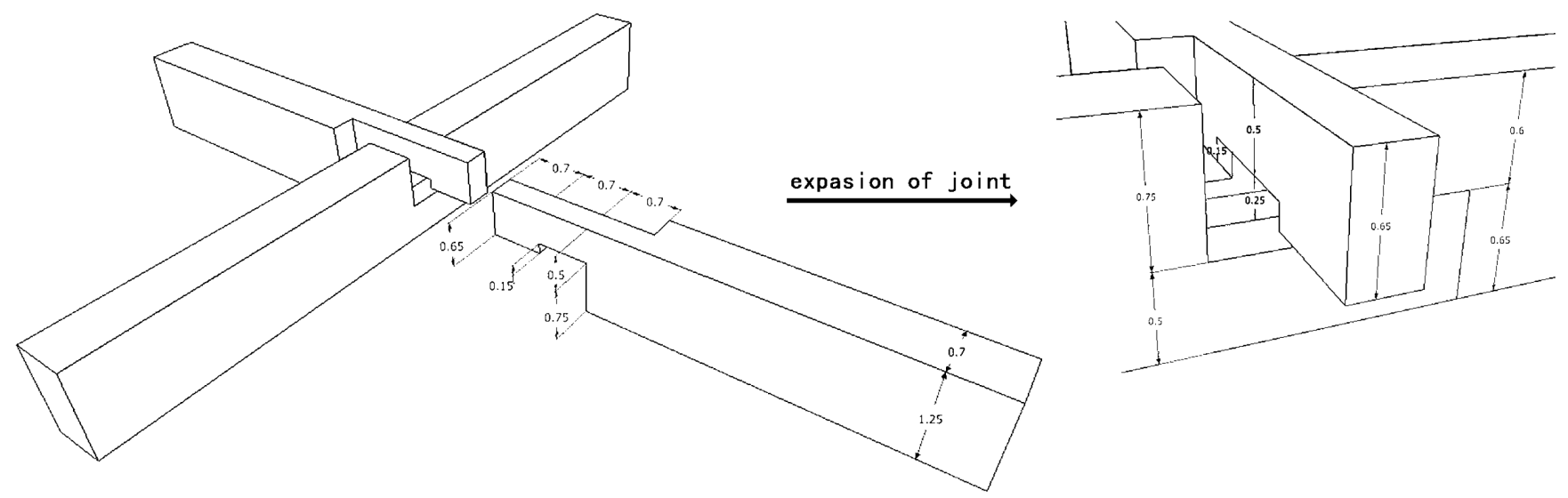

Fig. 3 Joint of the intersection of Crosspiece (Inserted bracket arms) in Ike's reconstruction plan (Unit:Shaku)

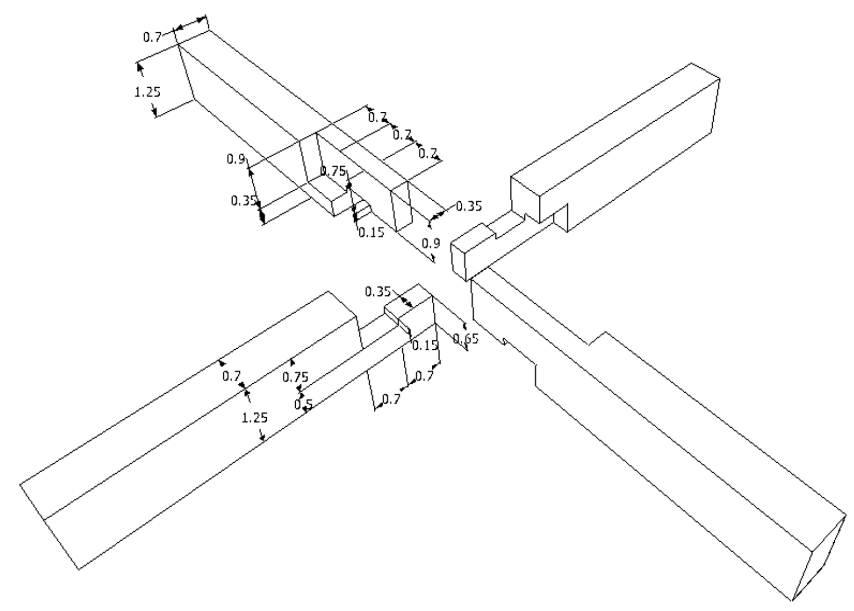

Fig. 4 Joint type1 (Unit:Shaku)

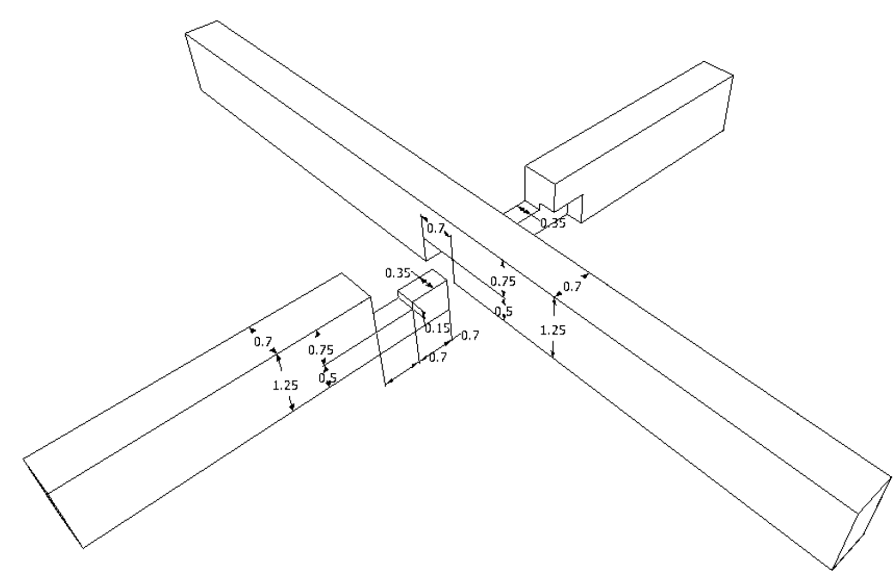

Fig. 5 Joint type2 (Unit:Shaku)
上端より厚五寸の楔打と成り、又側柱通の分は桁行の部を本仕ロに 依り抱合せ、梁行の貫を上より相欠きに落込み上端より同様楔打と せり。」

これを図に示したのが Fig.3 である。仕口は棟通柱と側柱とで異 なっており、棟通柱では四方より部材が差し込まれる四方差し、側 柱では一方の貫穴に双方より下木として部材を挿し込んだ後にもう 一方の貫穴に相欠きの組手を施した一丁材の挿肘木を差し入れる。

この仕口の形状・法復元はすでに池氏等によって以下のように なされている。棟通柱では、貫の先端を凡そ 4 分の 1 の断面に落と して片鬢太としたものを用いる（仕口 1 ・Joint type1）。下木では 貫穴の双方から貫を差し入れ、片鬢太を段欠きに抱き合わせ、他方 の貫と交差する部分に相欠きのための深さ 1 寸 5 分の段懸かりを施 す。「段懸かり七寸腰高五寸」の記述から、相欠き部の成が 5 寸、片 䰅太成は 6 寸 5 分となる。他方の貫は同形の片䰅太を上下逆に用い、 貫穴の双方から差し入れて下木と相欠きで組む。上木を差し入れる 際、鬢太先端の顎が下木の相欠き部に掛かる分を持ち上げる必要が あるため、貫穴上部に相欠きの深さ 1 寸 5 分の成を持つ楔代が開け られる。『修理要録』ではこの楔代成を「五寸」と表記するが、これ は側柱筋に挿入される一丁材の挿肘木の楔代成と誤って記したもの
と解される。側柱では、下木は同形である（仕口 $2 \cdot$ Joint type2）。 上木は相欠きで組まれるが、下木の相欠き部に掛かる分を持ち上げ る必要があるため、貫穴上部に相欠き部の成 5 寸の分の楔代が開け られる。

これらのうち棟通柱の仕口復元案では、上下の貫の組手形状を同 一とみなしているが、実はこの寸法では上木の䰎太下面が下木の相 欠き部上面より高くなり、両材の掛かりがない状態になってしまう ため、寸法の見直しが必要である。「段䀣かり七寸腰高五寸」の「腰 高」を鬢太中央の相欠き部の成ととらえたことは、側柱の梁行貫穴 の楔代成が概ね 5 寸であることが観察から知られることから、少な くとも下木の貫については正しいことがわかる。よって上下の貫が 相欠きとなるためには、下木と上木の鬢太の成が異なると考えざる を得ない。下木の「腰高」が 5 寸であるため、上木の「腰高」は部 材成 1 尺 2 寸 5 分から 5 寸を減じた 7 寸 5 分と推定される。この数 值により仕口の寸法を修正した（Fig. 4、Fig. 5)。

後述するように、貫穴上部にある楔代成は、外観からの目視で大 小 2 種が明確に判別できる。それぞれ実測数值として概ね成 1 寸 5 分と成 5 寸が得られ、上述の仕口形状から得られる楔代成の寸法と 一致した。大小の楔代成は 2 種の仕口、寸なわち楔代の小さい方が 「仕口 1」、大きい方が「仕口 $2 」$ と対応しているので、楔代成の配 
置状況を調査することによって、仕口・組手の形状を判別すること が可能となる。

池氏等の考察では、『修理要録』の記述から、棟通柱 4 本の貫仕 口を「仕口 1 」、隅柱を除く側柱 10 本の貫仕口を「仕口 $2 」$ とて 考察を進めている。しかしながら南大門を現地で観察したところ、 この配置に誤りがあることが判明した。また、貫の挿入順序により、 両仕口の上木と下木が逆になることもありうるが、その点について の視点が池氏等の考察には欠けている。従って、各柱、各層の貫穴 それぞれにつき、実態としていかなる楔代配置となっているか、そ こからいかなる仕口が想定されるのかを調べ直す必要がある。

\section{(2) 2 種の楔代の配置}

2 種の楔代は成の寸法が明瞭に異なるため、目視によって判別す ることが可能である。南大門の各層のうち、貫の入る層は層 2、層 4、層 7、層 12、層 15 、層 18 の 6 層である。柱の番付は『修理要 録』に従い Fig.6 のように設定する。各柱において、これらの 6 層 それぞれに開けられた桁行及び梁行両方向、そして隅柱等において は隅行方向の各貫穴につき、両面から目視による観察を行い、各楔 代の成を記録したものが Fig.7 である。写真により寸法を測定した ところ、成の小さい方は『修理要録』より判明する 1 寸 5 分に、成 の大きい方は 5 寸に概数対応寸ることが分かった。以降、成およそ 1 寸 5 分の楔代を「小」、成およそ 5 寸の楔代を「大」と標記する。 全体としては、池氏等が推定した通り、棟通柱では桁行、梁行と も楔代「小」すなわち「仕口 1」の形式であり、そして側柱では壁 付方向が「小」、手先方向が「大」、寸なわち「仕口 $2 」$ の形式であ るものが優勢である。

しかし、「は」通りの 3 本の柱には、これらの規則から外れる楔

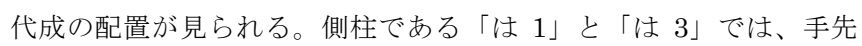
方向の楔代がすべての層で「小」となっている。これは、先に手先 方向の挿肘木を挿入した後、壁付きの通肘木を差し込んだことを示 しており、他の側柱における挿肘木の施工順序とは逆になる。

また、「は2」では、基本的に他の棟通柱と同様に桁行、梁行とも に「小」の楔代となっているが、層 2 のみ、桁行方向の楔代が「大」 となっている。この楔代配置は、側柱筋で想定される「仕口 2 」す なわち上木が一丁材となる形式であることを示寸ものと推定される。

つまり「は」通りでは、他の柱筋と異なる施工順序、あるいは部 材形状が採られていることになり、この柱筋が組立過程における特 異点であることが知られる。

その他、妻面にある側柱の「い2」と「へ2」の層 2、4、7 の枌行 方向に「大」の楔代が見られる。この 2 本の柱では、梁行方向の挿 肘木を先に入れてから桁行方向の挿肘木を挿し込んだものと推定さ れる。この点は池氏等の組立工程の復元案と合致する。

\section{(3)「は」通りの楔代配置の意味と「48 尺」の挿肘木の所在}

池氏等の考察では、側柱筋の仕口がす心゙て同一と捉えられており、 組立工程として、まず中央 3 柱間、すなわち「ろ」通りから「ほ」 通りにおける両側柱筋と棟通りの柱を立てて桁行に繋ぎ、次いで梁 行の挿肘木を順次挿入して軸部を固める、という順序が想定された。 しかし「は」通りの楔代配置が特異であるため、この組立工程は成 り立たない。

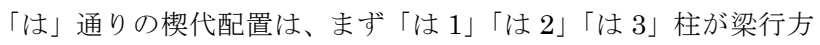
向の挿肘木によって繋がれ、次いで中央の「は $2 」$ の層 2 において、
桁行に 2 柱間を一丁材とする貫が挿入されたことを示している。桁 行に材を渡す際にはその両端の柱、すなわち「ろ2」「に2」も同時 に立てる必要があり、ここで「は」通りと「2」通りの 2 柱間ずつ を繋いだ十字形の構造体が組まれることになる。これは自立する安 定構造となるので、南大門の組立の起点としてこの構造体を形成す ることが意図されたものと考えられる。

とはいえ、南大門の柱は高さ $20 \mathrm{~m}$ に及ぶ格段に長大なもので、単 独で自立させるだけでも困難が伴う。そもそも最初「は」通りの柱 を 3 本立てるとなると、2 柱間を繋ぐ一丁材がない限りは、組立時 に一時的に極めて不安定な状態が生じることは否めない。

ここで思い起こされるのが、挿肘木の最長值「48 尺」である。先 述の通り、最長部材と目された隅行挿肘木の材長が 48 尺に満たな いため、この材長に比定される挿肘木が他にあることになる。一つ 目の候補は、「は」通りの層 2 を梁行に繋ぐ挿肘木である。「は 1 」、

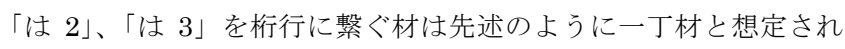
るため、これと交差する層 2 の正背面の挿肘木が一丁材であれば十 字形の構造体の支持として相応しく思われる。しかし正背面挿肘木 の 2 手目巻斗心間の距離は 45 尺 5 寸となり、48 尺に及ばない。

もう 1 点注目されるのが、上層組物の最下段に当たる層 12 の「胴 貫」である。この材は他の挿肘木と異なり、材端が巻斗より延びて 下層屋根面から突出するという、まるで上層組物のための足場のよ うな形式を有する。しかもこの材の端部の突出寸法は正背面で出が 異なり、かつ柱通りごとに端部突出寸法がまちまちであり、一丁材 を組手無しで柱に挿入しているかのような様相を呈している (Photo1)。この材の全長は概衫 48 尺である。そしてこの材は、組物 の一手目位置に巻斗を載せて上の肘木を支持しており、一手目の挿 时木としての機能も果たしているので、挿肘木と見なすことも可能 である。すなわち「48 尺」の挿肘木は、「は」通りの層 12 の胴貫を 一丁材とみることで、この部材に比定することができる。この材が 一丁材であるならば、柱を立てた状態で同貫を通すことは困難であ り、3 本の柱を地に伏せた状態であらかじめ胴貫を通して緊結し、 これを一度に立て起こす、という組立が想定される。

従って、「は」通りの梁行の構造体について以下の組立順序が想定 できる。まず 3 本の柱を伏せた状態で一丁材の胴貫を挿入し、それ を立て起こす。立て起こしの前後いずれかに、他の 6 層分の挿肘木 を挿入する。次いで、中央の「は 2 柱の層 2 に桁行方向の一丁材 を通すとともに、「ろ $2 」 「 に 2 」 の 2$ 柱を立てて十字形の構造体を 作り、自立する安定構造を形成する。この組立工程は、足場を設け ずに施工することが可能な極めて合理的な方法であり、「支度第一俊 乗房」と呼ばれた重源の面目躍如たるものがある。また、まず梁行

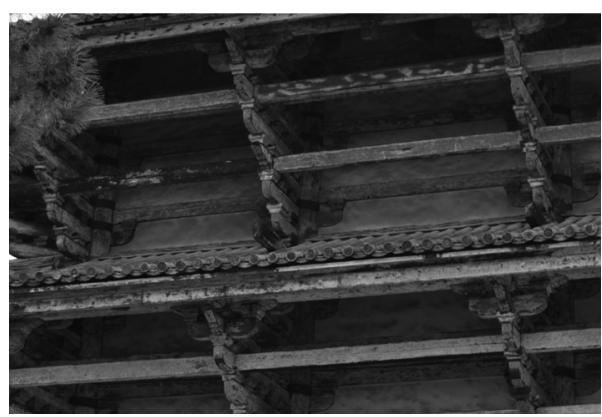

Photo1 Ends of DouNuki (胴貫) in Layer 12 


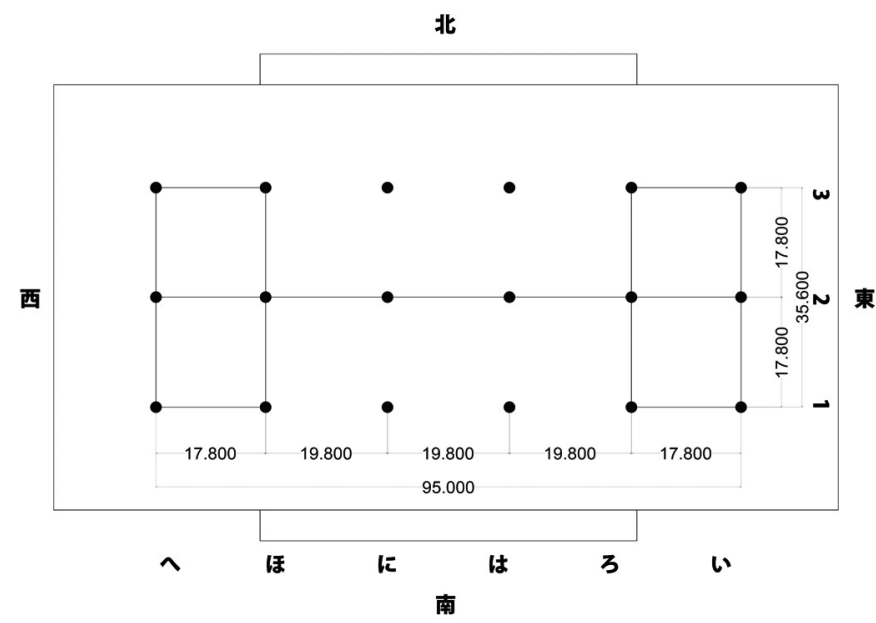

Fig. 6 Label system of columns (番付図) of Todai-ji Great South Gate

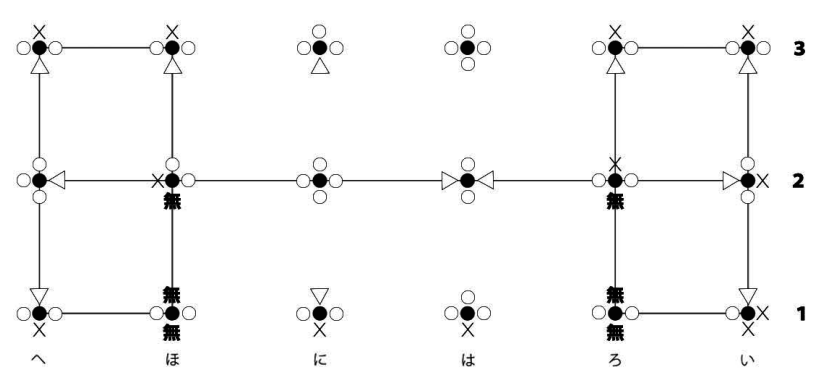

Layer 2

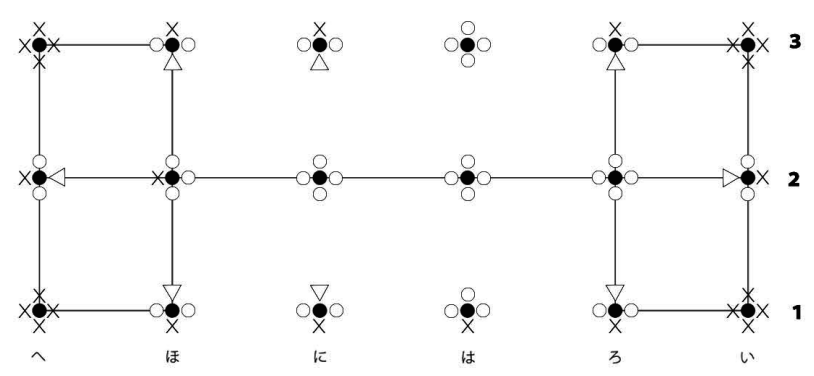

Layer 4

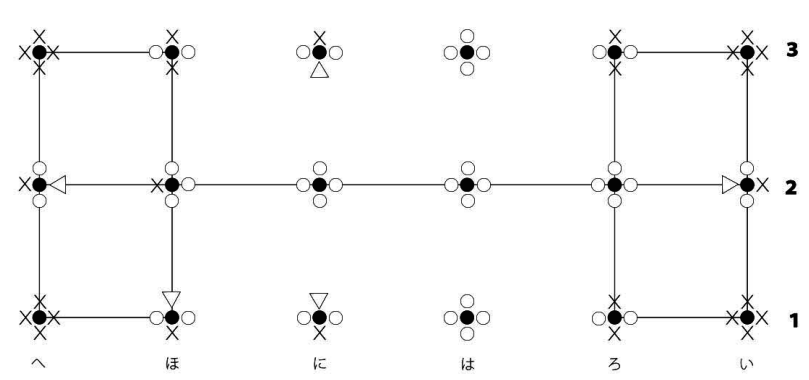

Layer 7

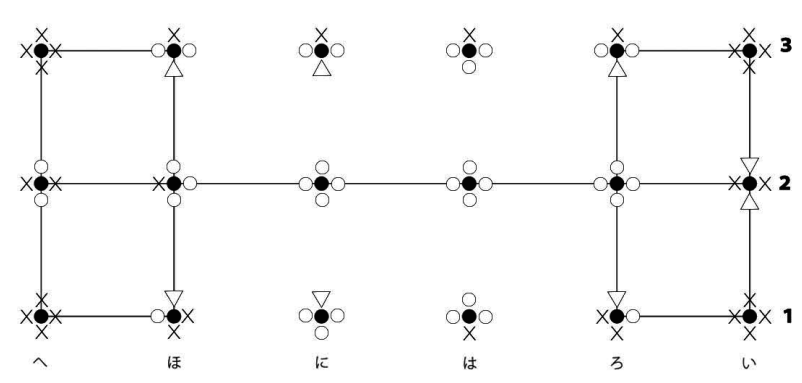

Layer 12

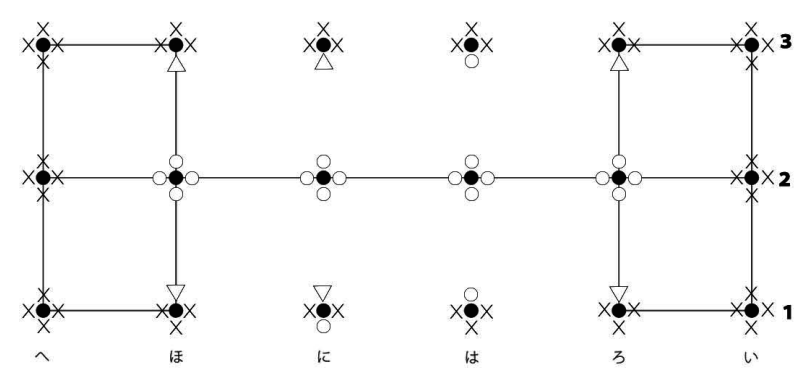

Layer 15

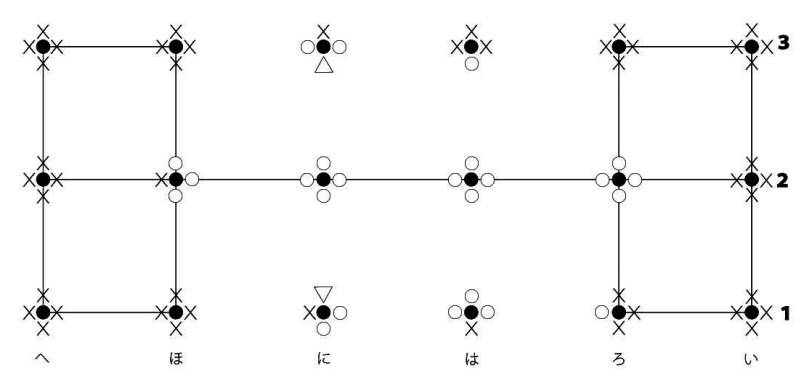

Layer 18

Fig. $7 \mathrm{~A}$ record of the size of Crosspiece holes and Wedge of Todai-ji Great South Gate based on field observation ( $\triangle$ : Joint type2; $\bigcirc$ : Joint type1; $\times$ : Can’t be judged. ) 


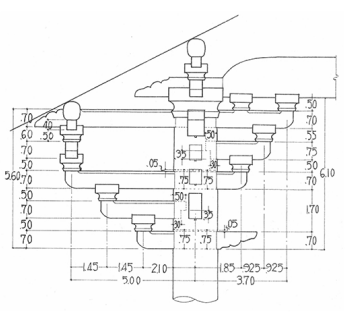

1 浄土寺浄土堂の側柱の 挿肘木

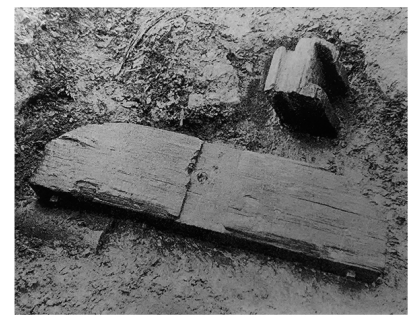

4 栢杜遺跡の出土品
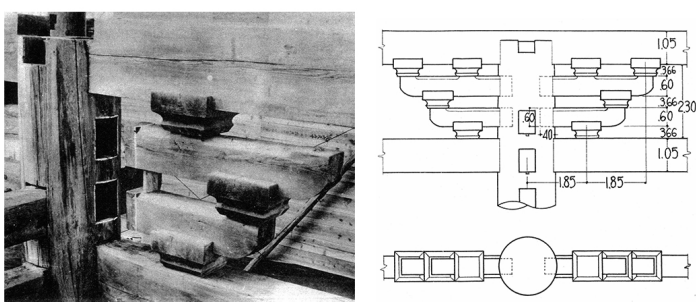

2浄土寺浄土堂の側柱の添承挿肘木

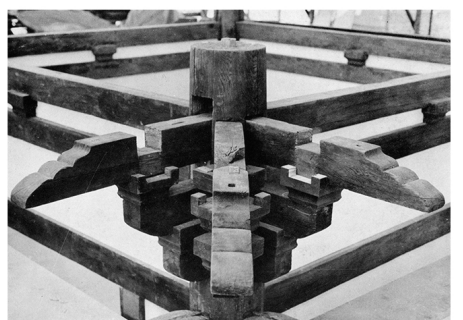

5 東大寺開山堂

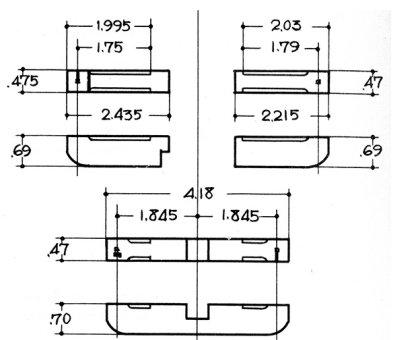

3浄土寺浄土堂の内柱の 二重添承插肘木

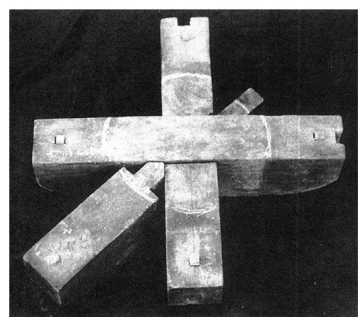

Fig. 8 Joint of Daibutsu-yo 注 7)

Table2 Some samples of Daibutsu-yo Inserted bracket arms

\begin{tabular}{|c|c|c|c|c|c|c|c|c|c|c|c|c|c|}
\hline 建築名 & 年代 & 建造者 & 大I & 部村の位普 & 部村名 & 重数 & 形態 & 柱との関係 & $\begin{array}{c}\text { 柱径(尺) }=\mathrm{a} \\
\text { (平柱を例と } \\
\text { する) }\end{array}$ & 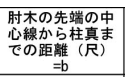 & $\begin{array}{l}\text { 柱の表面より出る } \\
\text { 距離 : b-a/2 (尺) }\end{array}$ & \begin{tabular}{|c|} 
时木の断面寸法 \\
(尺; 幅*成)
\end{tabular} & 文献根拋 \\
\hline \multirow{4}{*}{ 浄土寺浄土堂 } & \multirow{4}{*}{1192} & \multirow{4}{*}{ 重源 } & \multirow{4}{*}{ 豊後介紀清水 } & 側柱 & 㨂时木 & 多重 & $\begin{array}{c}\text { 出先、三手目は外䘽上で前後へ } \\
\text { 出る }\end{array}$ & 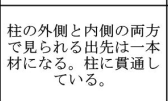 & \multirow{2}{*}{$\mid \begin{array}{c}1.70 \text { (柱天) } \\
\sim 1.80 \text { (柱下 } \\
\text { 部) }\end{array}$} & 三手目 : 7.335 & \begin{tabular}{|} 
外: $4.1 ;$; $： 0.95$ \\
$\sim$ 外: $4.15 ;$; $:$ \\
1.0
\end{tabular} & $0.47 * 0.69$ & 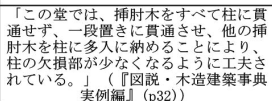 \\
\hline & & & & 㑡柱 & $\begin{array}{l}\text { (壁付) 添承 } \\
\text { 搏肘木 }\end{array}$ & 二重 & 側柱の左右側に出る。 & 柱の中に費通していな & & 一手具: $2.775 ;$ & \begin{tabular}{|c|} 
苸目: $: 1.875 \sim$ \\
$1.925 ; \quad=$ 手目:2.8 \\
$\sim 2.85$
\end{tabular} & $0.48 * 0.6$ & 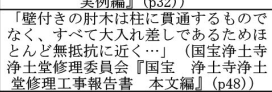 \\
\hline & & & & \multirow[b]{2}{*}{ 内柱 } & \multirow[b]{2}{*}{ 二重捕时木 } & \multirow[b]{2}{*}{ 二重 } & 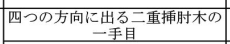 & 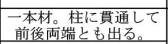 & \multirow[b]{2}{*}{$1.90 \sim 2.10$} & 1.85 & $0.8 \sim 0.9$ & $0.47 * 0.7$ & 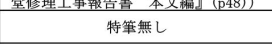 \\
\hline & & & & & & & $\begin{array}{c}\text { 四つの方向に出る二重㨉时木の } \\
\text { 二手目的 }\end{array}$ & 柱の中に貫通していな & & 2. 775 & 1. $725 \sim 1.825$ & $0.48 * 0.7$ & 特筆無し \\
\hline 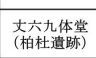 & 1195 & 重源 & 要確認 & 不明 & $\begin{array}{l}\text { 挿肘木兮、添 } \\
\text { 承掩肘木加 }\end{array}$ & 不明 & 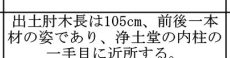 & 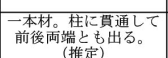 & 不明 & 約1.73 & 不明 & 不明 & 特筆無し \\
\hline \multirow{2}{*}{ 東大寺開山堂 } & \multirow{2}{*}{1200} & \multirow{2}{*}{ 重源 } & \multirow{2}{*}{ 東大寺系 } & \multirow{2}{*}{$\begin{array}{c}\text { 側柱 (内漣 } \\
\text { 柱) }\end{array}$} & 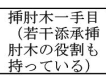 & \multirow{2}{*}{ 多重 } & \multirow[t]{2}{*}{ 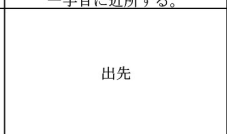 } & \multirow{2}{*}{$\begin{array}{l}\text { 一本材。桂に鿓通して } \\
\text { 前後同端とも出る。 }\end{array}$} & \multirow{2}{*}{$\begin{array}{l}1.056 \\
(0.320 \mathrm{~m})\end{array}$} & $0.825(0.250 \mathrm{~m})$ & 0.297 & \multirow{2}{*}{$\begin{array}{l}0.33(0.100 \mathrm{~m}) * \\
0.479(0.145 \mathrm{~m})\end{array}$} & \multirow{2}{*}{ 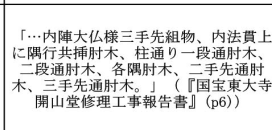 } \\
\hline & & & & & 挿肘木二、三 & & & & & 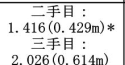 & $0.888 \sim 1.498$ & & \\
\hline \multirow[b]{2}{*}{ 東福寺三門 } & \multirow{2}{*}{$\begin{array}{l}1405 \\
\text { 銘] } \\
\end{array}$} & & \multirow[b]{2}{*}{ 東大寺関倸 } & 側柱 & 挿肘木一手目 & 多重 & 出先 & 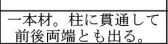 & \multirow{2}{*}{$\begin{array}{l}\text { 2. } 9007 \\
(0.879 \mathrm{~m})\end{array}$} & $\begin{array}{l}2.026(0.614 \mathrm{~m}) \\
2.129(0.645 \mathrm{~m}) * \\
.0 .6\end{array}$ & \multirow{2}{*}{$\begin{array}{l}\text { 一階: }: 0.679 * \\
\text { 二階: } 0.659\end{array}$} & \multirow{2}{*}{$\left|\begin{array}{c}0.729(0.221 \mathrm{~m}) * \\
0.950(0.288 \mathrm{~m})\end{array}\right|$} & \multirow[b]{2}{*}{ 特筆無し } \\
\hline & & & & 側柱 & 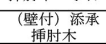 & 一重 & 侧柱の左右側に出る。 & 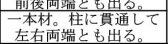 & & 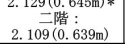 & & & \\
\hline
\end{tabular}

に貫によって固めた面としての構造体を形成し、次いで桁行に繋ぐ 構造及び工程は中国穿斗式建築に見られるものであり、技術の源流 を考えたときにも説得的と言えよう。

(4) 側柱に配置される添承挿肘木の仕口

もう一つ考えねばならないのが、『修理要録』で言及のない「添承 挿肘木」すなわち根肘木の仕口である。池氏は各添承挿肘木が二材 からなるものとしているが、これを他の大仏様建築の仕口と比較し て検証しよう（Fig.8）。

重源によって建てられた大仏様建物のうち、添承挿肘木が確認で きるものに、東大寺南大門のほか、浄土寺浄土堂、東大寺開山堂内 陣と丈六九体堂（柏杜遺跡）出土部材があり、また後の再建になる ものとして東福寺三門がある。添承挿肘木が一丁材で柱を貫通する ものは、浄土寺浄土堂の入側柱にある十字二重添承挿肘木の一手目、
東大寺開山堂の挿肘木一手目 (若干添承挿肘木の役割も持っている) と東福寺三門の（壁付）添承挿肘木である。しかし同じく壁付の添 承挿肘木である浄土寺浄土堂の側柱にあるものは一丁材ではなく、 二丁を柱の両側から挿した形になる。従って、重源によって建てら れた大仏様建築においても、插肘木の形と組手の仕様が一様ではな いことがわかる。

この原因は、柱径と肘木の寸法関係から推察できる。Table2 で示 すように、添承挿肘木が一丁材であるものは、その柱の面から外部 に挺出する長さが二丁になっているものより著しく短い。

東大寺南大門側柱の壁付添承挿肘木は、柱の表面より出る距離は 1.35 尺となり、この寸法は浄土寺浄土堂の壁付添承挿肘木より短い ものの、東大寺開山堂の二手目の 0.888 尺より長く、丁度その間に ある。一方、東大寺南大門の柱径は 3.3 尺に及ぶ巨大なものであり、 
柱径に対する添承挿肘木の出を比例で考えれば、一丁材となってい るものに近くなる。また、現地観察により、ここの貫穴楔代にも大 小の二つ種類が見出せるので、一丁材と見なすのに支障がない。

\section{5. 組立工程の復元}

以上を踏まえて、南大門の軸部組立工程を復元していこう。

(1) 部材数の修正

部材数は寸でに池氏等により詳しく論じられているが、本研究に よりいくつか修正を要する点があることが確認された。

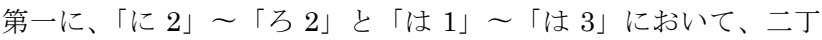
からなると考えられていた材が一丁材であったことを指摘した。こ の部分にのみ不規則な部材形状が現れることから、ここが組立工程 の起点となったものと推測される。

第二に、添承挿肘木の仕口形式を修正する。池案では、添承挿肘 木を 2 丁からなると見なしているが、本論では前述の大仏様建築の 参照により、一手目と二手目を区別し、添承挿肘木の一手目が一丁 材であると推定する。

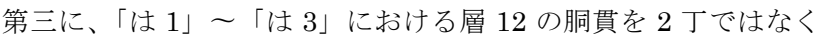
48 尺の一丁材と推定する。

\section{（2）組立工程の復元}

南大門の組立工程について直接記述した史料はないが、同じく重 源によって再建された東大寺大仏殿の造営記録である『東大寺造立 供養記』に、天平創建と鎌倉再建の大仏殿を比較した以下の記述が ある注 8)。

「造寺間古与今勝劣有十二也、一者昔奉鉡之間経三箇年而八箇度也、 今者三十九日間奉鋳了、二者昔構庇柱而勵営作故庇柱之遠至手搔大 路。今無其煩以成、三者柱口径三尺五寸今五尺也、四者昔者寄廿五 箇国経六十一年、今以両國之用途以造四箇宝殿経十余年成一大事也、 五者昔築佛後之山而失荘厳、今引捨佛後之山崩去堂前之岡茲増荘厳 成眺望、六者昔用四五尺釘而成大堂之固、今不用釘而弥健固也（後 略)」

第二項に、創建時大仏殿が足場を構えて造営したため足場が遠く手 搔大路にまで至ったが、鎌倉再建に当たってはそれほどの煩いがな かったことを指摘している注9)。これまで考察してきたように、南 大門の組立の起点となる「は $2 」$ 柱廻りの組立順序は、大規模な足 場を用いずに安定構造を形成することとよく合致している。つまり 南大門においても、大規模な足場を用いずに安定構造を確保しなが ら組立を進めたと考えられる。

以上を踏まえて、特に柱の仕口形状に注意しながら、組立工程を まとめていこう（Fig. 9, Fig. 10）。なお、添承挿肘木の組立につい ては、一手先のものは貫及び挿肘木の組立前に組む必要がある一方 で、二手先のものは二手目の添承挿肘木が 2 丁材であるために貫及 び挿肘木の組立後に挿入することが可能である。一丁材と想定され る貫及び挿肘木下には、層 2 では添承挿肘木は用いられず、層 12 では二手先が用いられ、いずれも組立順序に影響がないため、以下 では省略する。

（1）「は 1」「は 2」「は 3」の柱を立て、層 2 の正背面一丁材の 挿肘木を入れて緊結し、「は列」を面として固める。あるいは地上に
3 本の柱を伏せた状態で一丁材の挿肘木を入れて緊結し、構造体を 建て起こす。

（2）柱「ろ 2」「に2」を立柱し、層 2 の析行に一丁材を入れ、「は 列」「 2 列」が十字をな寸架構を形成する。これは自立する安定構造 をなし、組立の起点となる。

（3）（4）この十字架構の他層にそれぞれ梁行挿肘木と桁行通肘 木を入れる。

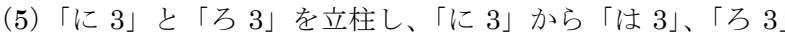
から「は3」へ通肘木を入れる。ただしこの工程は、(6)、(7)の工程 後に行われる可能性もある。

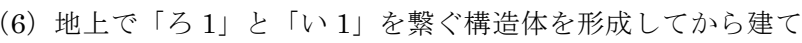
起こし、「は 1 」、「い 1」、「い3」から挿肘木を入れ、「い3」ないし 「い1」から一本材の挿肘木を入れる。

（7）「に1」を立柱し、「に1」から「は1」に通肘木を入れる。 同時に、「い列」と「ろ列」の他の挿肘木を入れる。

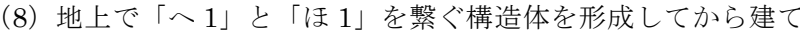

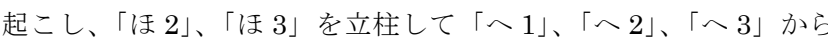
挿肘木を入れる。そして「い2」から桁行方向の挿肘木を補足する。

（9）「へ3」を立柱して「へ3」、「へ1」から挿肘木を入れる。

（10）「へ2」を立柱して「へ列」、「ほ列」、「に列」の挿时 木を入れる。

（11）「へ2」から挿肘木を入れる。ここで主要な架構が自立し た構造体として完成する。

（12）隅行の部材を入れ、そして構造材以外の部材を入れて架構 を完成する。

\section{6. 軸部組立工程復元の意義}

以上の検討により、『修理要録』の記載と現場で観察した貫穴楔 代成の寸法に基づき、東大寺南大門の軸部主要部材の組立工程を解 明した。その工程は、池氏等の想定した工程が、桁行を繋いだ後に 梁行きを繋ぐという、桁行と梁行とに工程上の前後関係があるとい う見立てとは異なるものであった。

また、大仏様建築の構造形式は中国民間の建築形式である穿斗式 と類似するものであることが指摘されてきたが、組立工程に着目す ると、それとは異なるものであると考えざるを得ないことになる。 現存する穿斗式の建築は、梁行の柱列を地上に並べた状態で貫によ って繋ぎ、一つの面を構成する構造体とした後、それを建て起こし、 隣の柱列の構造体と桁行に貫で接続していく組立工程をとる。すな わち梁行と桁行とで構造上の主従が明確に存在する。

東大寺南大門では、まず十字形の自立する構造体を組み、これを 組立の原点として他の部分を順次組み立てていくもので、梁行と桁 行には構造上も組立工程上も主従がない。穿斗式における地上で面 状の構造体を形成して建て起こす建設技術を一部で用いた可能性が あるものの、その構造理念は本質的に異なっている。それは大規模 な足場を用いずに、いかにして $20 \mathrm{~m}$ もの長大な柱を自立させ安定構 造を形成するか、という問題設定から組み立てられたものであった だろう。

構造体の形成と足場の機能を同時に果たすこの構造は、この建築 を設計する際に組立工程も同時に設計していたことを示している。 建築の構造、意匠と組立工程を同時に設計したという点は、同じく 


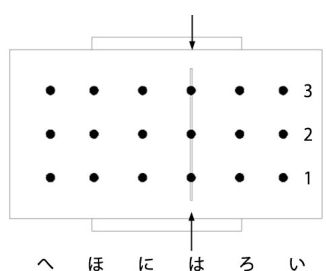

（1「は」列を面として構成する。
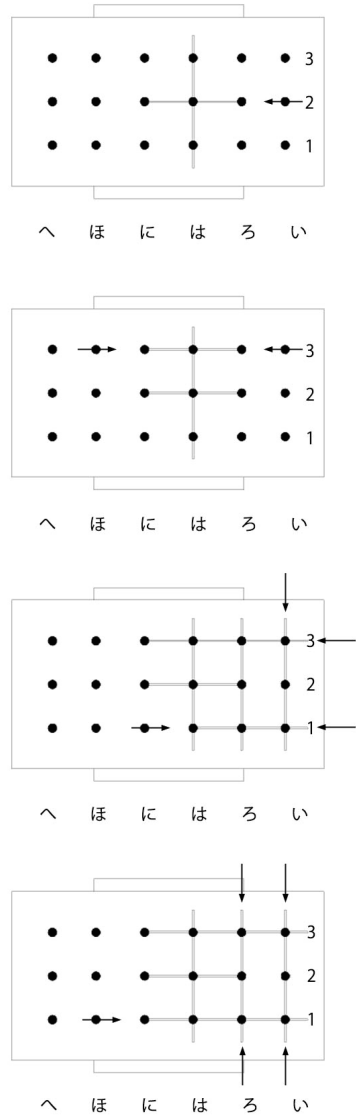
を形成する。 る。

(5)「に3」と「ろ3」を立柱し、

「は3」へ通肘木を入れる。

*(6)、(7)の工程後でも可能 挿肘木を入れる。

(7)「に1」を立柱し、「に1」から 入れる。

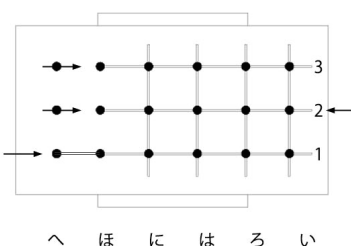

(8)「へ1」と「ほ1」を地上で繋いで から立ち上げ、「ほ2」、「ほ3」を 立柱して「へ1」、「へ2」、「へ3」 から挿肘木を入れる。「い2」から桁 行方向の挿肘木を補足する。

(2)「ろ2」から「に2」に一丁材の 挿肘木を入れ、自立する十字の架構

(3),(4)上部の挿肘木と通肘木を入れ

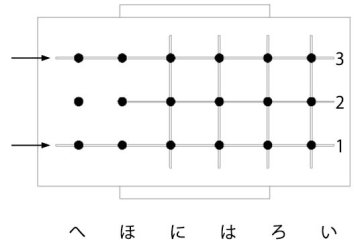

(9)「へ3」を立柱して「へ3」、「へ1」 から挿肘木を入れる。

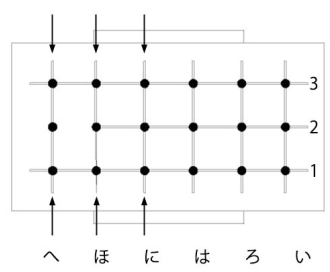

(10)「へ2」を立柱して「へ列」、

「に3」から「は3」、「ろ3」から

「ほ列」、「に列」の挿肘木を入れる。

(6)「ろ1」と「い1」を地上で繋いで から立ち上げ、「は1」、「い1」、 「い3」から挿肘木、通时木を入れ、 「い3」ないし「い1」から一丁材の

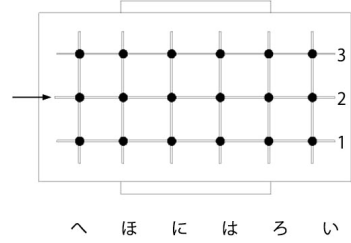

(11)「へ2」から挿肘木を入れる。 「は1」に通肘木を入れる。同時に、 「い列」と「ろ列」の他の挿肘木を

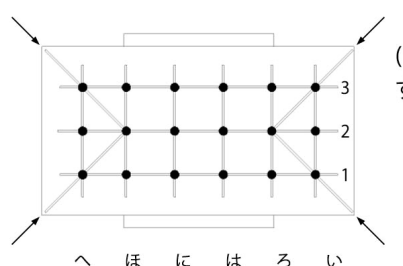

(12)隅行の部材を入れて架構を完成 する。

Fig. 9 Construction process of Todai-ji Great South Gate

重源による大仏様建築である浄土寺浄土堂にも共通している注 10)。 いずれも和様建築の組立工程とは根本的に異なるものであり、この ことは大仏様建築における本質的な特質と認めることができる。

大仏様建築において構造・意匠と組立工程とが同時に設計された とする論点は、大仏様の技法研究だけでなく、その源流を考える既 往研究の中でもこれまで論じられてこなかった。この設計方法の源 流はどこにあるのか。本論文で得られた大仏様建築の特質は、大仏 様建築の源流に関する新たな視点を提起するものともなろう。

\section{謝辞}

東大寺南大門の現地調査にあたり、東大寺執事森本公穣様、技師 今西良男様に多大な便宜をおはからい頂きました。記して感謝致し ます。

\section{参考文献}

1) Todai-ji Great South Gate Shurikōjijimusho: Tōdaijinandaimonshi Oyobi Showashuriyōroku, Tōdai-jinandaimon Shurikōjijimusho, 1930. 4 (in Japanese)

東大寺南大門修理工事事務所: 東大寺南大門史及昭和修理要録, 東大寺 南大門修理工事事務所, 1930. 4
2) Hiraoka Meikai: Tōdai-jishi, Nara: Tōdai-ji, 1943. 10 (in Japanese)

平岡明海：東大寺史，奈良：東大寺，1943. 10

3) Shimizu Kōshun: Tōdai-ji, Kyoto: Kyoto Inshokan, 1945. 10 (in Japanese)

清水公俊：東大寺, 京都 : 京都印書館, 1945. 10

4) Kokuhō jōdo-jijōdodō shuriiinkai：Kokuhō Jōdo-jijōdodō Shurik ōjihōk-okusho Text $\cdot$ Figure, 1959 (in Japanese)

国宝浄土寺浄土堂修理委員会 : 国宝浄土寺浄土堂修理工事報告書 本文 編・図版編, 1959

5) Nara Prefectural Cultural Property Preservation Office: Kokuhō Tōdai-jikaizandō Shurikōjihōkokusho, 1971 (in Japanese) 奈良県文化財保存事務所編：国宝東大寺開山堂修理工事報告書, 1971

6) Ōkawa, N. : Banshō (the third edition), Hosei University Press, 1974, 10 (in Japanese)

大河直躬：番匠 第 3 刷, 法政大学出版局, 1974. 10

7) Sugiyama, S. : Chōgen No Kenchiku Gihō To Kayanomori Iseki (Architectural Technique of the Priest Chōgen Seen at the Site of Kaya-no-mori in Yamashiro Province), Buddhist Art 105, Maini -chi Newspapers, 1976. 01 (in Japanese) 杉山信三：重源の建築技法と柏杜遺跡，佛教藝術 105，毎日新聞社， 1976. 01

8) Ike, K. and Suzuki, T. and Kataoka, Y. : Tōdai-jinandaimon No Kō seibuzai Jikubu No Hijiki To Nuki (The Structural Members of 

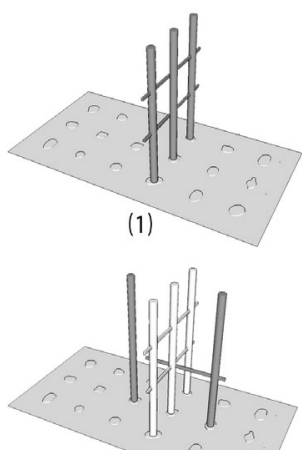

(2)

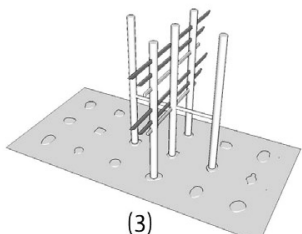

(3)

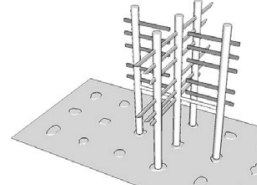

(4)
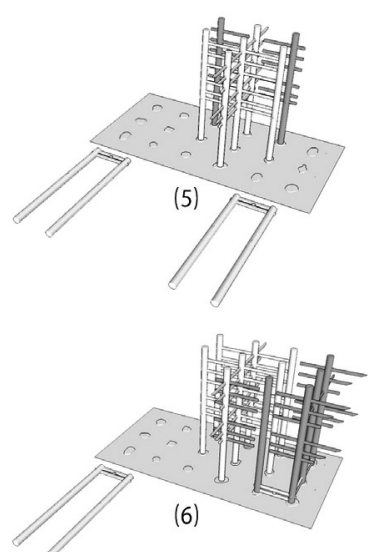

主要架構の建立過程復原
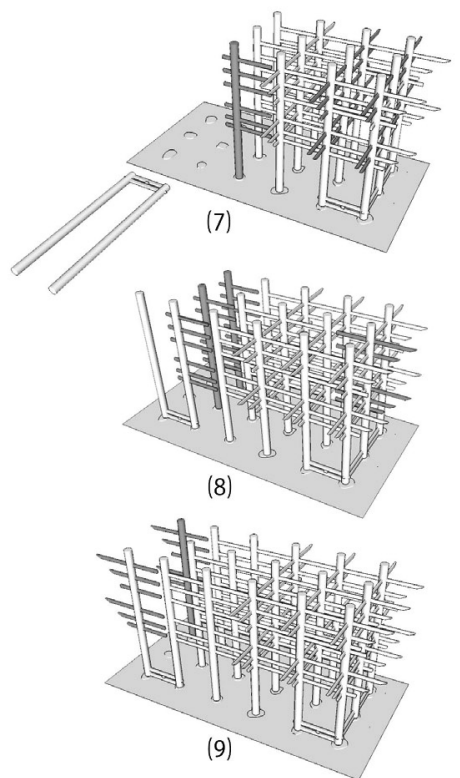

(9)
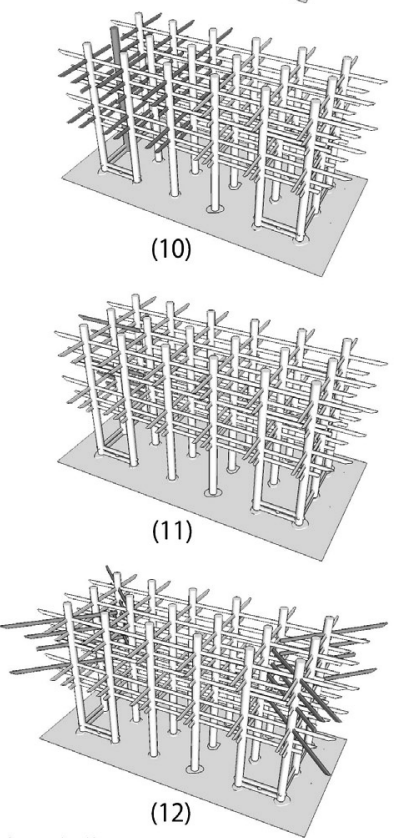

(12)

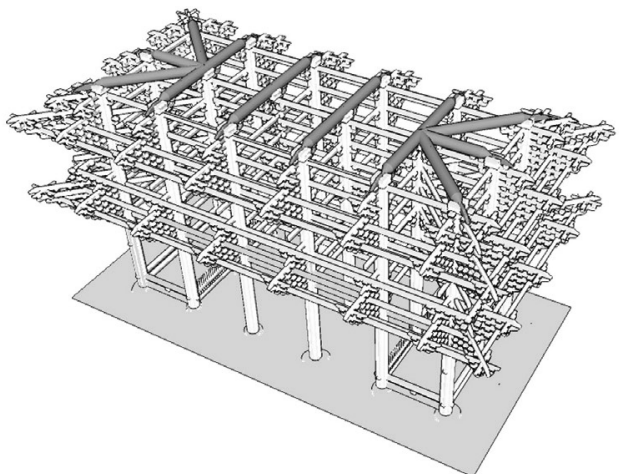

大虹梁下の主要な架構部分

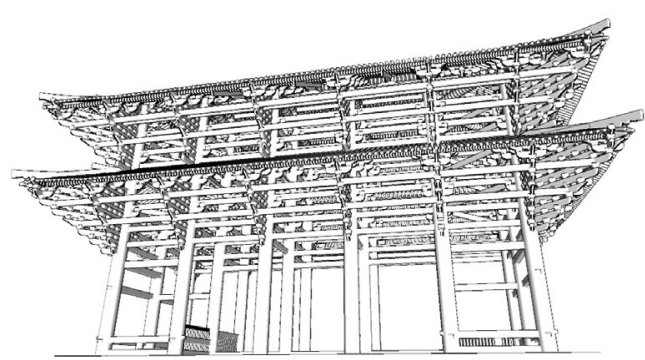

全体の架構の示意図

Fig. 10 3D Construction process of Todai-ji Great South Gate

Todaiji Nandaimon The Bracket Arms And The Crosspiece), Journal of Architecture, Planning and Environmental Engineering(Transa -ctions of AIJ), No. 453, pp. 127-136, 1993. 11 (in Japanese) 池浩三、鈴木樹、片岡靖夫: 東大寺南大門の構成部材 軸部の肘木と貫, 日本建築学会計画系論文報告集 第 453 号, pp. 127-136, 1993. 11

9) Gomi, F. : Daibutsu Saiken (Rebuilt the Great Buddha Statue), Kōdansha Ltd., 1995. 09 (in Japanese) 五味文彦：大仏再建，講談社, 1995. 09

\section{注}

注 1) 参考文献 8

注 2) Fig.1 の断面図を参照。この図面では一部の部材の表現を省略した。

注 3) 参考文献 1 の本文では「樌」と表記している。

注 4) 参考文献 1 。東大寺南大門の柱間寸法は奈良時代創建時の寸法が踏襲さ れており、17.8 尺、19.8 尺はそれぞれ天平尺で 18 尺、20 尺にあたる。

注 5)「第八章 諸種の統計」：参考文献 1

注 6) 同上。
注 7) 写真の出典は以下の通りである。
$1 ， 2 ， 3$ : 参考文献 4
4: 参考文献 7
5 : 参考文献 5

注 8) 『東大寺造立供養記』（『大日本佛教全書』第 121 冊 東大寺叢書一、 有精堂出版部、1932）。

注 9)「庇柱」について、参考文献 8 において池氏等は文字通り庇柱と解し、 その立入れに手間取ったために建方の順番を待っている残りの柱が転害大 路まで列をなしたとするが、創建大仏殿の想定構造形式が庇柱の立入れに 手間取るものとは考えにくい。一方、大岡實はこの「庇柱」を足場の柱と 捉え、それが転害門まで届いたと解釈しており（大岡實「鎌倉時代再建の 東大寺」『南都七大寺の研究』中央公論美術出版、1966、p.327）、本稿で は大岡の解釈を妥当なものととらえる。

注 10) 参考文献 4 


\section{COMPONENTS AND ASSEMBLING PROCESS OF TODAI-JI GREAT SOUTH GATE FROM AN OBSERVATION OF CROSSPIECE HOLES AND THEIR WEDGES}

\section{Lin LIN $^{* 1}$ and Shigeatsu SHIMIZU*2}

\footnotetext{
${ }^{* 1}$ Grad. Student, Dept. of Architecture, Graduate School of Science and Technology, Kyoto Institute of Technology, M.Eng.
} ${ }^{* 2}$ Prof., Dept. of Architecture, Graduate School of Science and Technology, Kyoto Institute of Technology, Dr.Eng.

Todai-ji Great South Gate(東大寺南大門), built in the early Kamakura period, has been studied as a representative example of Daibutsu-yo(大仏様) architecture. There are many studies about it from the aspects of the style and technique of Daibutsu-yo, the relationship with Chinese Song Dynasty architecture, the construction organization of Todai-ji Temple, the achievements of Chogen(重源) and Todai-ji Great South Gate itself. Studies from the viewpoint of Daibutsu-yo technic are mostly focusing on the detail. On the other hand, Daibutsu-yo should have introduced mainly for the reconstruction of the Great Buddha Hall of Todai Ji Temple(東大寺大仏殿) as a huge building, the whole structure and its assembly process should be considered in an important meaning.

Among many precedent studies，「東大寺南大門の構成部材一軸部の肘木と貫」 by Ike Kozo(池浩三) focused on the assembly process of Todai-ji Great South Gate, it based on the Report book of repair construction（『東大寺南大門史及 昭和修理要録』). In this paper, they paid attention to the joint of shaft horizontal inserted to the column of Todai-ji Great South Gate, examined constituent components of it, made a model of it and estimated its assembly process. The result showed that the construction of Todai-ji Great South Gate was very reasonable and dynamic. In their study, Todai-ji Great South Gate was considered as perfect mirror symmetry, but an observation of crosspiece holes and wedges in this research proved that there are many irregular positions. Therefore, it was necessary to examine the type and arrangement of main components of Todai-ji Great South Gate, and to reconsider the construct sequence of column, crosspiece and inserted bracket arms (Sashihijiki)

This paper was based on an observation of crosspiece holes and wedges in field survey, re-inspected the joints and shape of main components of Todai-ji Great South Gate's main framework recorded by the Report book of repair construction, revised their position and then aimed to restore the assembly process. The examination is carried out by the following method.

1. Examined the peculiar description method in Report book of repair construction. 2. Based on the observation in field survey, made the actual condition of crosspiece holes and wedges clear, analyzed the shape of joint, the shape of crosspiece inserted to the crosspiece holes vertically and horizontally and their assembly order. 3 . Re-inspected the types and dimensions of components recorded by the Report book of repair construction, revised their position. 4 . Based on the above restored the assembly process of its main framework.

The result showed that even Daibutsu-yo has some common characters with Chinese Chuandou (穿斗式), it was obvious that it has its unique assembly process, which brought up a new perspective for discussing the origin of Daibutsu-yo. 